\title{
CHARGE CARRIER TRANSPORT AND RECOMBINATION IN DISORDERED MATERIALS
}

\author{
G. Juška, K. Arlauskas, and K. Genevičius \\ Department of Solid State Electronics, Vilnius University, Sauletekio 3A, LT-10222 Vilnius, Lithuania \\ E-mail: kestutis.arlauskas@ff.vu.lt
}

Received 8 July 2016; accepted 23 September 2016

\begin{abstract}
In this brief review the methods for investigation of charge carrier transport and recombination in thin layers of disordered materials and the obtained results are discussed. The method of charge carrier extraction by linearly increasing voltage (CELIV) is useful for the determination of mobility, bulk conductivity and density of equilibrium charge carriers. The extraction of photogenerated charge carriers (photo-CELIV) allows one to independently investigate relaxation of both the mobility and density of photogenerated charge carriers. The extraction of injected charge carriers (i-CELIV) is effective for the independent investigation of transport peculiarities of both injected holes and electrons in bulk heterojunctions. For the investigation of charge carrier recombination we proposed integral time-of-flight (TOF) and double-injection (DI) current transient methods. The methods allowed us to obtain the following significant results: to determine the reason of the conductivity dependence on electric field strength and temperature in the amorphous and microcrystalline hydrogenated silicon and $\pi$-conjugated polymers, the time dependent Langevin recombination, the impact of morphology on charge carrier mobility, the reason of reduced Langevin recombination in RR-PHT (regioregular poly(3-hexylthiophene))/PCBM (1-(3-methoxycarbonyl)propyl-1phenyl-[6,6]-methanofullerene) bulk heterojunction structures - 2D Langevin recombination; and to evaluate that the mobility of holes is predetermined by off-diagonal dispersion in poly-PbO.
\end{abstract}

Keywords: disordered materials, mobility, recombination

PACS: 72.20Jv, 72.80Le, 73.50Jt, 88.40jr

\section{Introduction}

The random distribution of atoms of disordered materials causes specific energy distribution of the density of electronic states, and, as a consequence, the description of charge carrier transport is different and more complicated than that in the crystalline materials. In 1977, P.W. Anderson and N.F. Mott received the Nobel Prize for the description of electronic processes in disordered structures. Besides a huge impact of their scientific work on understanding of charge carrier transport in disordered systems, their ideas stimulated the development of electronic devices on the basis of amorphous and microcrystalline materials: xerography, chalcogenide and amorphous hydrogenated silicon solar cells, amorphous field effect transistors, etc. In 2000, A. Heeger, A. MacDiarmid, and $\mathrm{H}$. Shirakava were awarded the Nobel Prize for the synthesis and application of conductive polymers. This stimulated the development of organic thin-film electronics: OLED, OFET, photovoltaics, etc.

In disordered materials, due to high charge carrier scattering, the classic Hall effect and magnetoresist- ance measurements cannot be applied for investigation of charge carrier transport. On the other hand, in high conductivity materials the direct measurement of charge carrier mobility using the time-of-flight (TOF) method is impossible, because the dielectric relaxation time $\left(\tau_{\sigma}\right)$ is shorter than the transit time $\left(t_{\mathrm{tr}}\right)$ of charge carriers through the inter-electrode distance and the drifting packet of charges is screened by equilibrium charges before it arrives at an opposite electrode. Also, after the pulse of voltage is applied onto electrodes, the equilibrium charge carriers redistribute electric field in the inter-electrode space. In order to decrease the $t_{\mathrm{tr}}$ the thickness of the layer may be reduced, however, this increases the capacitance $(C)$ of the sample, and, as a consequence, limits the shortest delay time $\left(t_{\mathrm{del}}\right)$ between the pulse of voltage and the pulse of light, during which the electric field relaxes to the stationary magnitude. Another problem is that for the layers of submicron thickness it is difficult to achieve the surface absorption of light, which is preferred for the TOF method.

This brief review is about the investigation methods of charge carrier transport and recombination in 
thin layers of disordered materials, and about some interesting results obtained by those methods.

\section{Methods and their applications}

We have proposed the method of equilibrium charge carrier extraction by linearly increasing voltage (CELIV) [1, 2] (Fig. 1). The experimental setup and circuitry in the CELIV technique is the same as in TOF, except that a linearly increasing voltage pulse with the slope $A=U / t_{\text {pulse }}$ is applied to the sample with blocking contacts.

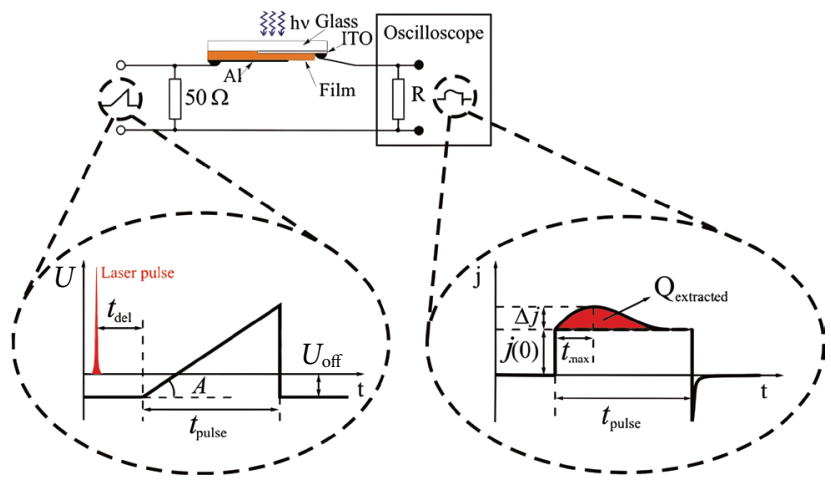

Fig. 1. CELIV setup and time diagram.

For measuring the parameters of equilibrium charge carriers this method does not need photoexcitation pulses, thus the measurement equipment is less complicated. Also one can avoid large spikes of capacitance current, which makes the TOF measurements of small-charge current difficult when the delay time between the rectangular pulse of voltage and the exciting pulse of light is short. The extraction current transient can be used to obtain the capacitance of the structure

$$
\varepsilon \varepsilon_{0} / d=j(0) / A
$$

The drift mobility of charge carriers is

$$
\mu=\frac{2 d^{2}}{3 A t_{\text {max }}^{3}(1+0.36 \Delta j / j(0))}
$$

when $\Delta j \leq j(0)$, i. e. $\tau_{\sigma} \geq t_{\text {tr }}$ and

$$
\mu=\frac{\tau_{\sigma} d^{2}}{A t_{\max }^{3}} \text { when } \Delta j \gg j(0) \text {, i. e. } \tau_{\sigma} \ll t_{\text {tr }}
$$

The density of equilibrium charge carriers is

$$
\rho_{0}=\frac{2}{e d} \int_{0}^{\infty} \Delta j \mathrm{~d} t \text {. }
$$

The bulk conductivity of the structure is

$$
\sigma_{\text {bulk }}=\left.\varepsilon \varepsilon_{0} \frac{\mathrm{d} j}{\mathrm{~d} t}\right|_{t=0} / j(0) .
$$

Using the CELIV method we have investigated various amorphous and microcrystalline hydrogenated silicon and $\pi$-conjugated polymers as well as their bulk heterojunction layers [3-5]. This method enables one to determine the reason of conductivity dependence on electric field strength and temperature: whether this dependence is caused by mobility or density of charge carriers [3]. Also it enables one to compare the reasons of charge carrier mobility dependence on electric field strength: whether it is caused by stochastic transport, by micromobility dependence on electric field strength, or by release probability from trapping levels [6]. This method also allows determining - by changing the delay duration between the two sequent voltage pulses, according to Eq. (4) - the recovery kinetics of equilibrium charge carrier density.

On the basis of CELIV measurement results it was demonstrated that in a weak electric field region the charge carrier mobility decrease with electric field measured using TOF is erroneous [⿰亻] The latter is due to the fact that, after the pulse of voltage is applied onto sample electrodes, the equilibrium charge carriers redistribute the electric field in the inter-electrode space, i. e. with a low electric field $\tau_{\sigma} \ll t_{\text {tr }}$ thus the necessary condition of the TOF method is not fulfilled.

Disadvantages of the CELIV method are the following: in disordered materials the charge carrier mobility usually depends on the electric field strength, but in the CELIV method the electric field is increasing with time, so the charge carrier mobility, that is calculated from the measured $t_{\max }$, is determined at $E=A t_{\max } / d$ with an error [8]; it is not clear what mobility and of which charge carriers is determined. If the densities of charge carriers are comparable, the current maxima of holes and electrons separate when the ratio of charge carrier mobility is greater than 3 .

An extraction method of photogenerated charge carriers (photo-CELIV) enabled us to independently measure both the mobility and density of photogenerated charge carriers and their relaxation after photoexcitation [9]. This is particularly important for investigating the behaviour of charge carriers in disordered structures, which are characterized by stochastic transport of carriers when the charge carrier mobility decreases with increasing the delay after photo-generation. It is demonstrated in Fig. 2 that this is not caused by the mobility dependence on 
charge carrier density, because the $t_{\max }$ is independent of the magnitude of exciting light pulse.

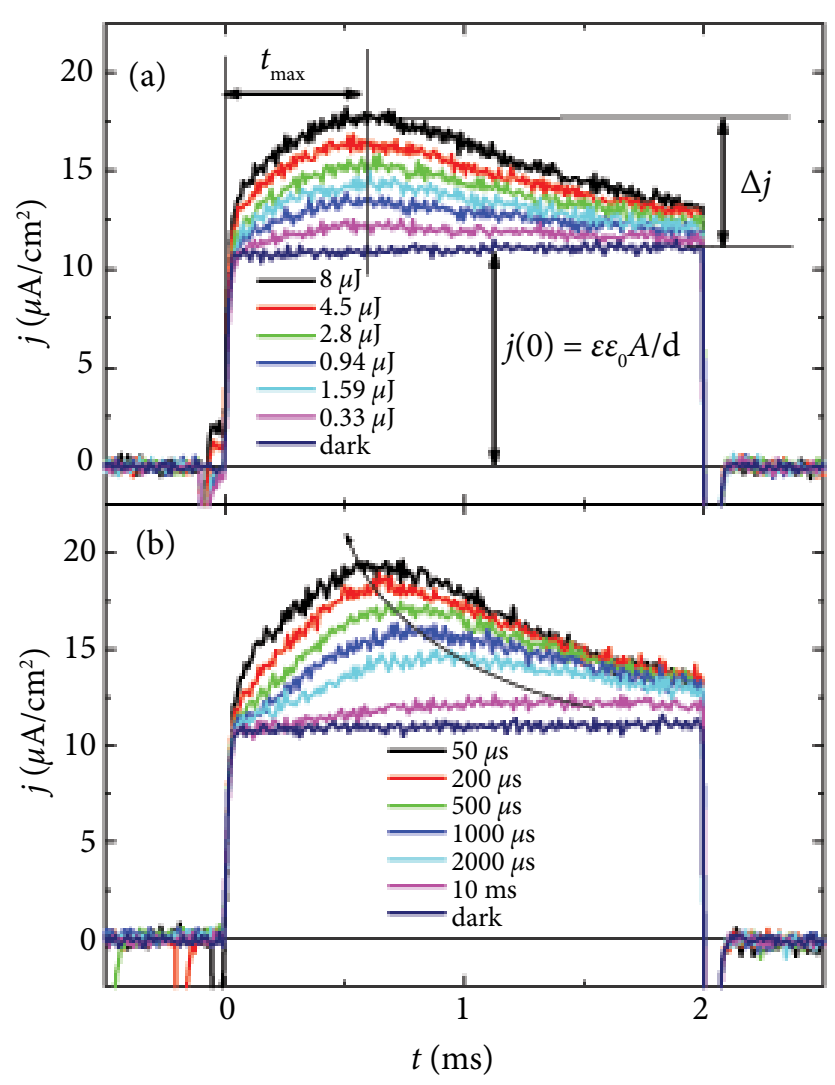

Fig. 2. Photocurrent transients of photo-CELIV at different intensity of light pulse and fixed delay time (a), and at different delay time $t_{\text {del }}$ and fixed intensities of light pulse (b) in the RRa-PHT layer (coloured online).

In order to analyse the transport features quantitatively, the theory of the photo-CELIV is extended to account for the dispersive nature of charge transport [10]. In the case of dispersive transport, the motion of the drifting packet of the photogenerated charge slows down with time, resulting in the time-dependent drift mobility:

$$
\mu(t)=C t^{-(1-\alpha)},
$$

where the dispersive parameter $\alpha$ can be easily determined from the time of photo-CELIV current maximum dependence on $A$ :

$$
t_{\max } \sim A^{\frac{-1}{1+\alpha}} \text {. }
$$

One of the most important features, which limits the efficiency of a solar cell, is the recombination of charge carriers. In organic materials the short, compared to the Coulomb radius, hopping distance of charge carriers causes the Langevin-type bimolecular recombination. The time-dependent relaxation of charge carrier mobility is the cause that the investigation of charge carrier recombination from photocurrent transients, after their excitation by a short pulse of light, is inaccurate. The experimental results of $\mu(t)$ and $n(t)$ obtained by photo-CELIV demonstrate that the Langevin recombination coefficient $\left(\beta_{\mathrm{L}}\right)$ is time dependent (Fig. 3) [11].

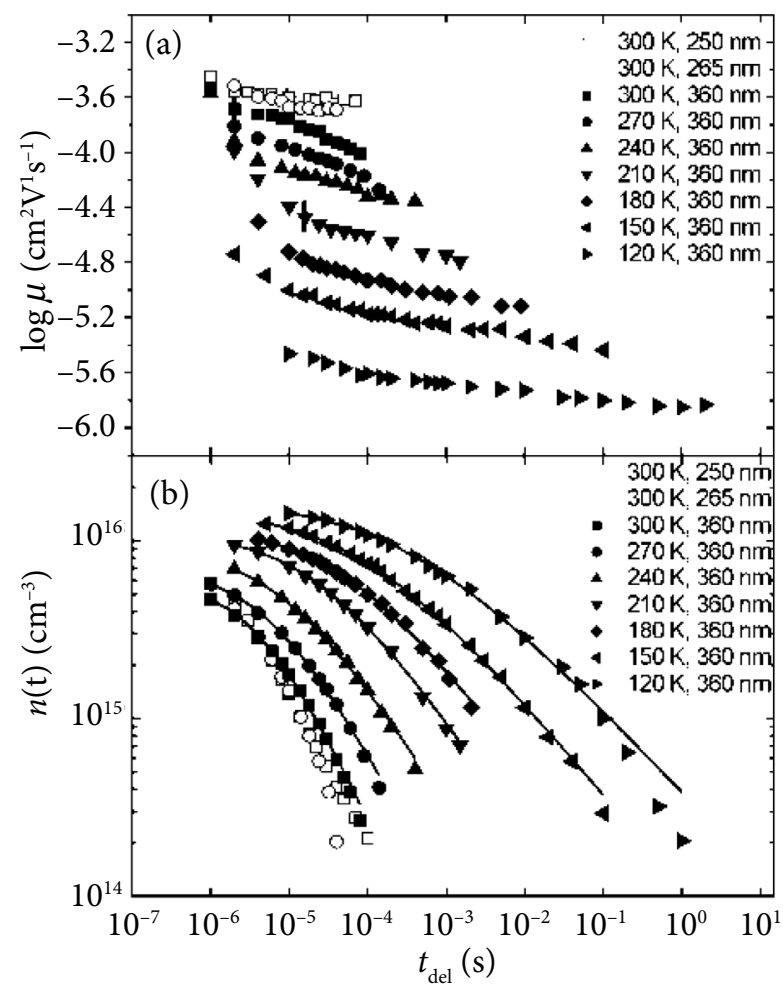

Fig. 3. Mobility (a) and density (b) of extracted charge carriers versus the delay time for MDMO-PPV/PCBM blend. Density relaxation of charge carriers fitted according to the time-dependent Langevin recombination coefficient.

In high efficiency organic solar cells the strongly reduced Langevin recombination is observed. We propose convenient ways for the determination of the Langevin recombination reduction factor $\beta / \beta_{\mathrm{L}}$. Using photo-CELIV, while increasing the intensity of photo-exciting light, the current of photo-CELIV saturates and from this magnitude the ratio $\beta / \beta_{\mathrm{L}}=j(0) /$ $\Delta j_{\text {sat }}$ can be estimated [12].

Despite the merits, there are some disadvantages of the photo-CELIV method. This method can only be used to measure the mobility of majority charge carriers, and also, using photo-CELIV errors may occur due to the influence of the initial distribution and recombination of the photogenerated charge carriers [12, 13]. In Ref. [12] the ways to avoid these shortcomings are discussed: first, one should use an intensity of pulse 
of the exciting light that the condition $\Delta j<j(0)$ is fulfilled and, when the absorption coefficient value is known, one should apply the correction factor in Eq. (2). Moreover, those techniques do not allow separating movement of holes from electrons in thin films. Another disadvantage is that the intrinsic electric field of the open circuit voltage of OSC must be compensated by the external voltage $\left(U_{\text {off }}\right)$, however, if an intrinsic electric field $\left(U_{\text {ins }}\right)$ is distributed in the inter-electrode space, after its compensation the injection from the electrodes is obtained. To avoid the latter effect there is a possibility to switch off an electric circuit for the delay time between the pulse of light and voltage ramp. However, in this case their redistribution also occurs.

The extraction of injected charge carriers (i-CELIV) is a method that overcomes the previously mentioned disadvantages [14]. The i-CELIV technique is based on independent investigation of hole and electron transport in bulk heterojunction OSC [15, 16]. This technique requires blocking a layer between the bulk heterojunction and one of the electrodes. Charge carriers are injected from the opposite electrode with offset, pushed towards the interface and extracted by linearly increasing voltage. The mobility of injected charge carriers across the layer is estimated from time $t_{1}$ when the extraction space charge limited current is equal to $j(0)$ (see Fig. (4):

$$
t_{1}=\frac{\pi d_{s}}{2 \sqrt{2 \mu A}} .
$$

The mobilities and their dependences on electrical field, $\mu \sim E^{\gamma}$, could be established by changing the rate of linearly increasing voltage $A$ according to

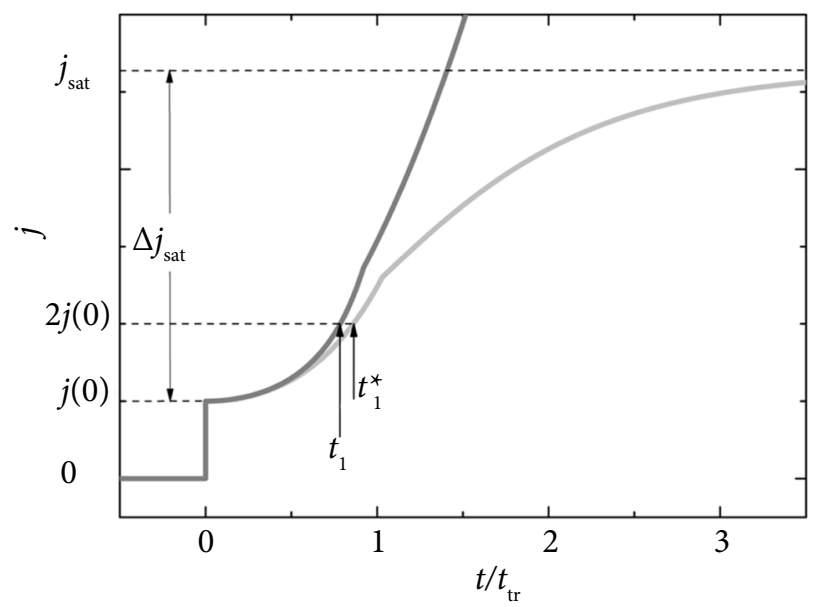

Fig. 4. The numerically modelled transient of i-CELIV current (dark grey line) and the same taking into account the capacitance (light grey line) of a blocking layer $\left(t_{1}^{*} / t_{1} \sim j_{\text {sat }} / j(0)\right.$, see [16]).

$$
t_{1} \sim A^{-\frac{\gamma+1}{\gamma+2}}
$$

The main advantages of the extraction of injected charge carriers are the following: there is no influence of the recombination, the distribution of charge carriers is well defined, and the mobility of both holes and electrons can be measured independently.

For estimation of the mobility along the transporting layer the OFET current transient method was proposed [17, 18] (see Fig. 5):

$$
\mu=0.38 \frac{L^{2}}{t_{\mathrm{d}} U_{\mathrm{SD}}} .
$$

In combination with i-CELIV it allows one to determine the impact of morphology on charge carrier mobility. Using this method an amount of charge carriers at the insulator/semiconductor interface can be estimated as well as its influence on the estimation of mobility. This is a frequent error while estimating the mobility from volt-ampere characteristics.

As mentioned above, the TOF technique could be problematic for mobility measurements in certain cases, however, an integral TOF $\left(R C>t_{\mathrm{tr}}\right)$ could be used for investigation of the initial mobility
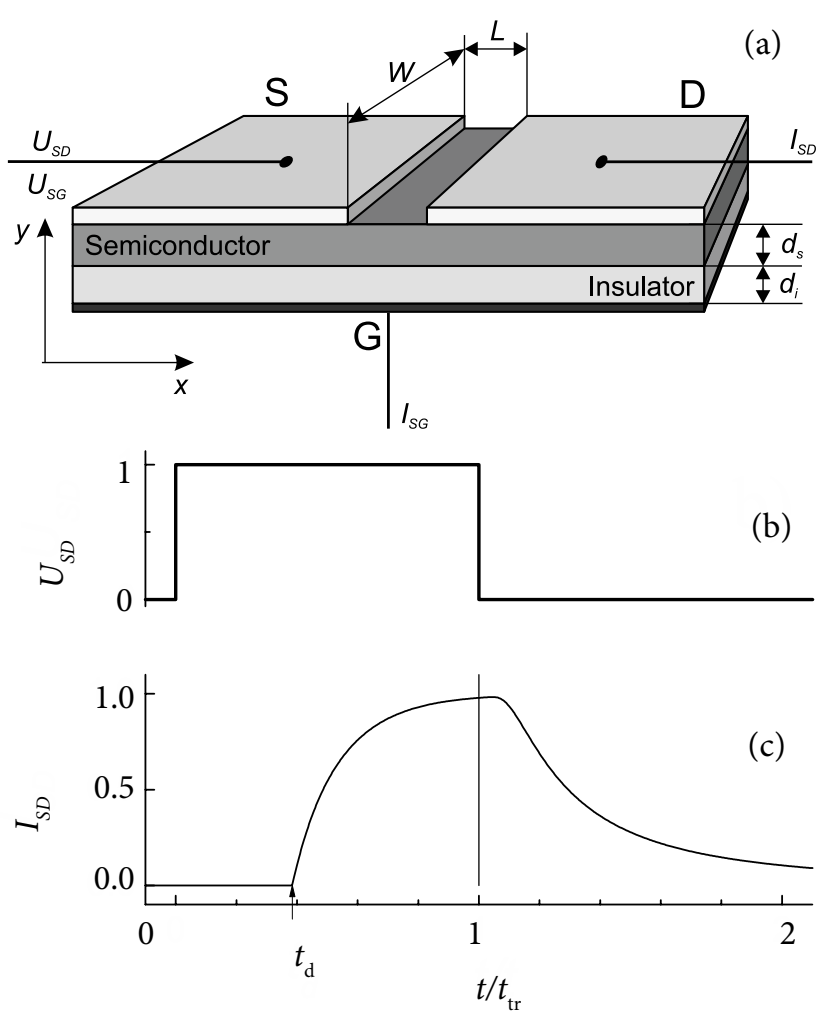

Fig. 5. The structure of an organic field effect transistor (a), the voltage pulse applied between the source and drain $U_{\mathrm{SD}}$ (b), and the numerically modelled corresponding current transient $(c)$. 
(immediately after the photogeneration) of charge carriers during their thermalisation [19] and recombination. Since the quantum efficiency of photogenerated charge carriers is strongly field- and wavelength-dependent, but very weakly dependent on temperature, we can separate the initial transport distance of photoexcited charge carriers $\left(l_{f}(E)\right)$ from the distance of their thermalisation. We found the initial drift distance to be temperature- and wavelength-independent, but strongly dependent on electrical field.

An integral TOF could also be used as a convenient method for the determination of the reduction factor of Langevin recombination. The charge carrier reservoir is created by strongly absorbed high intensity light pulse and by measuring extraction time $t_{\mathrm{e}}$ and an amount of extracted charge $Q$ [see Fig. 6]. The Langevin recombination reduction factor could be estimated as $\beta / \beta_{\mathrm{L}}=C U t_{\mathrm{tr}} / Q t_{\mathrm{e}}[20]$.

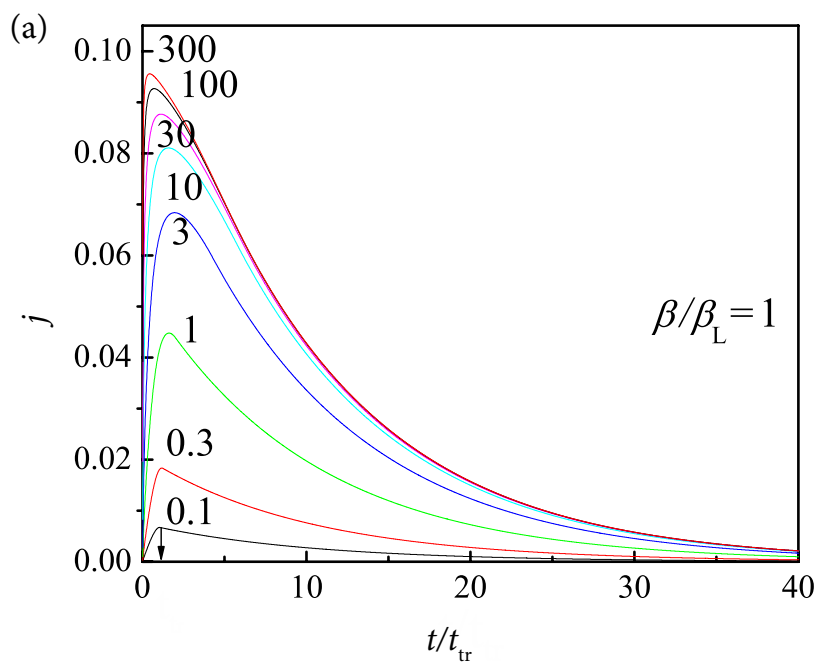

(b)

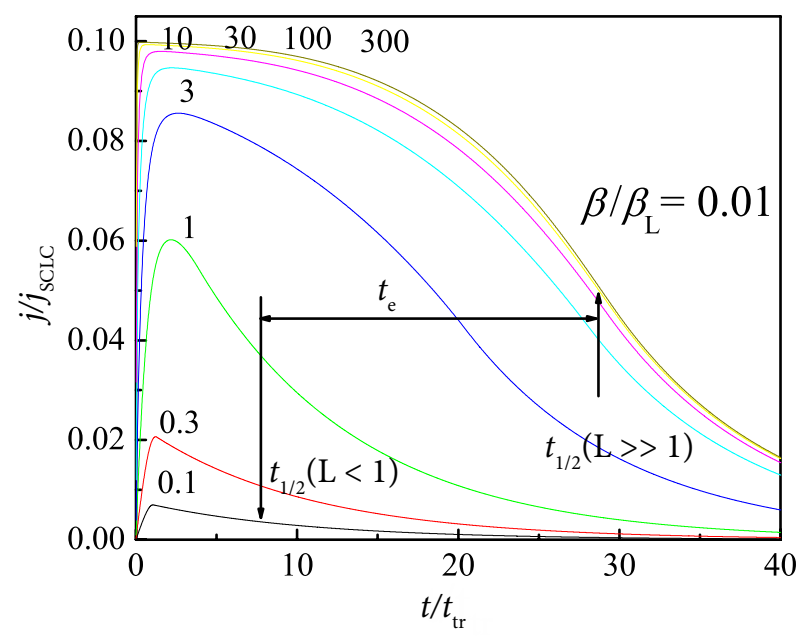

Fig. 6. Numerically modelled integral TOF current transients $\left(R C=10 t_{\text {tr }}\right)$ at different intensities of light and different reduction factors of Langevin recombination (coloured online).
For the estimation of bimolecular recombination coefficient the double-injection (DI) current transient technique was proposed [21-23]. It allows direct determination of the bimolecular recombination coefficient or the reduction factor of Langevin recombination (see Fig. 7). The experimental setup for DI transient measurements is the same as in the TOF technique, except that no light is required for DI since charge carriers are injected from electrodes. The square voltage pulse in the forward bias with the amplitude $U$ is applied to the sample, electrons and holes are injected into the film, and the response current is recorded by the oscilloscope. A simple analytical derived formula was proposed for the calculation of the ratio of the bimolecular recombination coefficient and Langevin coefficient [23]:

$$
\frac{\beta}{\beta_{\mathrm{L}}} \approx\left(\frac{j_{\mathrm{SCLC}}}{j_{\mathrm{s}}}\right)^{2}
$$

where $j_{\text {s }}$ is saturation current, $j_{\text {SCLC }}$ is space charge limited current (Fig. 7).

Using Eq. (11) it is possible to measure the electric field and temperature dependence of the bimolecular recombination coefficient directly from DI transients without using data fitting and without setting up transport-recombination models. Therefore, this technique is a very powerful tool to study the charge carrier transport, recombination, and deep trapping in organic semiconductors.

One of main areas of application of thin organic layers is organic solar cells. As mentioned above, one

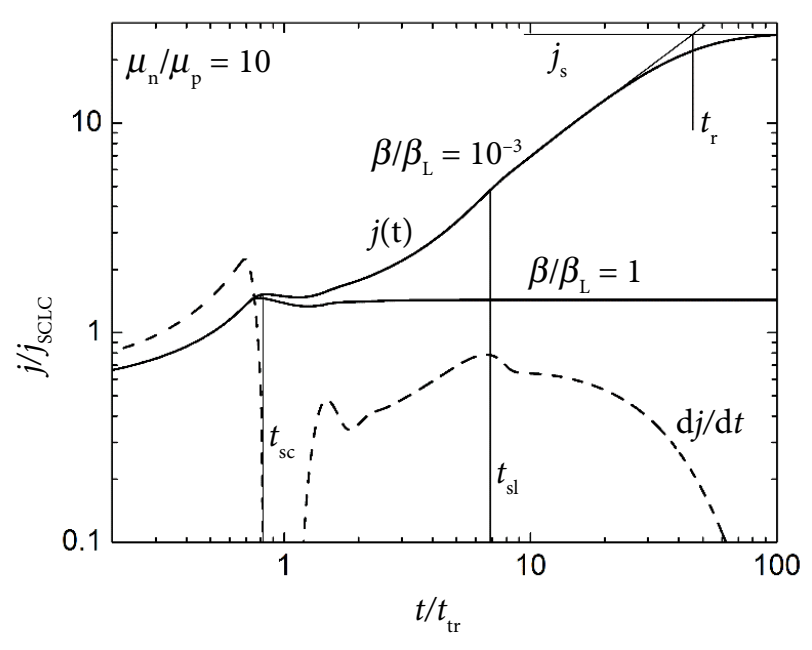

Fig. 7. Numerically modelled transients of double injection currents into a dielectric in cases of the Langevin and reduced bimolecular recombination. The derivative of current in the case of reduced recombination is also shown. 
of the most important factors, which limits the efficiency of a solar cell, is the recombination of charge carriers. In RR-PHT (regioregular poly(3-hexylthiophene))/PCBM (1-(3-methoxycarbonyl)propyl1phenyl-[6,6]-methanofullerene) bulk heterojunction structures (efficiency of those solar cells exceeds $10 \%$ ), the bimolecular recombination coefficient has been experimentally estimated to be $10^{3}-10^{4}$ times lower than the Langevin recombination coefficient. All experiments (integral TOF, DI, photo-CELIV) confirmed that it is caused by the 2D Langevin recombination process [24, 25] when after annealing a lamellar structure is formed in RR-PHT.

Other possible application of the amorphous materials is X-ray medical imaging detectors [26. The development of such detectors requires a comprehensive analysis of the key performance parameters, which are largely governed by transport and recombination mechanisms. Polycrystalline lead oxide $(\mathrm{PbO})$ has a long and successful history of application in Plumbicons for X-ray medical imaging, however, studies of transport and recombination of charge carriers has never been performed in the polycrystalline $\mathrm{PbO}$, despite a continuous interest in this promising material. Here, the transport of mobile charge carriers (holes) and the recombination are evaluated using the photo-CELIV method. We show that the transport of holes is predetermined by coordinate dispersion in poly- $\mathrm{PbO}[10]$.

\section{Acknowledgements}

We would like to thank the colleagues who have substantially contributed to our research: Dr. N. Nekrašas, Dr. M. Viliūnas, Dr. G. Šliaužys, and G. Juška Jr.

\section{References}

[1] G. Juška, K. Arlauskas, M. Viliūnas, and J. Kočka, Extraction current transients: New method of study of charge transport in microcrystalline silicon, Phys. Rev. Lett. 84, 4946-4949 (2000), http:// dx.doi.org/10.1103/PhysRevLett.84.4946

[2] A. Pivrikas, N.S. Sariciftci, G. Juška, and R. Osterbacka, A review of charge transport and recombination in polymer/fullerene organic solar cells, Prog. Photovolt. Res. Appl. 15, 677-696 (2007), http://dx.doi.org/10.1002/pip.791

[3] G. Juška, K. Arlauskas, M. Viliūnas, K. Genevičius, R. Osterbacka, and H. Stubb, Charge transport in $\pi$-conjugated polymers from extraction current transients, Phys. Rev. B 62, 16235-16238 (2000), http://dx.doi.org/10.1103/PhysRevB.62.R16235

[4] G. Juška, M. Viliūnas, K. Arlauskas, N. Nekrašas, N. Wyrsch, and L. Feitknecht, Hole drift mobility in $\mu \mathrm{c}-\mathrm{Si}: \mathrm{H}$, J. Appl. Phys. 89, 4971-4974 (2001), http://dx.doi.org/10.1063/1.1359436

[5] A.J. Mozer, N.S. Sariciftci, L. Lutsan, D. Vanderzande, R. Österbacka, M. Westerling, and G. Juška, Charge transport and recombination in bulk heterojunction solar cells studied by the photoinduced charge extraction in linearly increasing voltage technique, Appl. Phys. Lett. 86, 112104 (2005), http://dx.doi.org/10.1063/1.1882753

[6] K. Genevičius, R. Österbacka, G. Juška, K. Arlauskas, and H. Stubb, Charge transport in $\pi$-conjugated polymers from extraction current, Thin Solid Films 403-404, 414-417 (2002), http://dx.doi. org/10.1016/s0040-6090(01)01583-8

[7] G. Juška, K. Genevičius, K. Arlauskas, R. Österbacka, and H. Stubb, Charge transport at low electric fields in $\pi$-conjugated polymers, Phys. Rev. B 65, 233208 (2002), http://dx.doi.org/10.1103/ PhysRevB.65.233208

[8] S. Bange, M. Schubert, and D. Neher, Charge mobility determination by current extraction under linear increasing voltages: Case of nonequilibrium charges and field-dependent mobilities, Phys. Rev. 81, 035209 (2010), http://dx.doi.org/10.1103/ PhysRevB.81.035209

[9] R. Osterbacka, A. Pivrikas, G. Juška, K. Genevičius, K. Arlauskas, and H. Stubb, Measuring the time relaxation of photogenerated charge carriers in organic materials, Curr. Appl. Phys. 415, 534-538 (2004), http://dx.doi.org/10.1016/j.cap.2004.01.013

[10] O. Semeniuk, G. Juska, J.-O. Oelerich, M. Wiemer, S. D. Baranovskii, and A. Reznik, Charge transport mechanism in lead oxide revealed by CELIV technique, Sci. Rep. 6, 33356 (2016), http://dx.doi. org/10.1038/srep33359

[11] A.J. Mozer, G. Dennler, N.S. Sariciftci, M. Westerling, A. Pivrikas, R. Osterbacka, and G. Juska, Time-dependent mobility and recombination of the photoinduced charge carriers in conjugated polymer/fullerene bulk heterojunction solar cells, Phys. Rev. B 72, 035217 (2006), http://dx.doi. org/10.1103/PhysRevB.72.035217

[12] N. Nekrašas, K. Genevičius, M. Viliūnas, and G. Juš$\mathrm{ka}$, Features of current transients of photogenerated charge carriers, extracted by linearly increased voltage, Chem. Phys. 404, 56-59 (2012), http://dx.doi. org/10.1016/j.chemphys.2012.01.008

[13] G. Juška, N. Nekrašas, V. Valentinavičius, P. Meredith, and A. Pivrikas, Extraction of photogenerated charge carriers by linearly increasing voltage in the case of Langevin recombination, Phys. Rev. B 84, 155202 (2011), http://dx.doi.org/10.1103/ PhysRevB.84.155202

[14] G. Juška, N. Nekrašas, and K. Genevičius, Investigation of charge carriers transport from extraction current transients of injected charge carriers, J. Non-Cryst. Sol. 358, 748-750 (2012), http:// dx.doi.org/10.1016/j.jnoncrysol.2011.12.016 
[15] A. Armin, G. Juska, M. Ullah, M. Velusamy, P.L. Burn, P. Meredith, and A. Pivrikas, Balanced carrier mobilities: not a necessary condition for high-efficiency thin organic solar cells as determined by MIS-CELIV, Adv. Energy Mater. 4, 1300954 (2014), http://dx.doi.org/10.1002 aenm.201300954

[16] J. Važgèla, K. Genevičius, and G. Juška, i-CELIV technique for investigation of charge carriers transport properties, Chem. Phys. (April 2016), http://dx.doi.org/10.1016/j.chemphys.2016.04.005

[17] G. Juška, N. Nekrašas, K. Genevičius, and A. Pivrikas, Current transients in organic field effect transistors, Appl. Phys. Lett. 102, 163306 (2013), http://dx.doi.org/10.1063/1.4803054

[18]G. Juška, N. Nekrašas, K. Genevičius, and T. Grigaitis, The determination of charge carrier mobility from the current transients in organic field effect transistor, J. Appl. Phys. 116, 023702 (2014), http://dx.doi.org/10.1063/1.4887798

[19] G. Juška, K. Genevičius, R. Osterbacka, K. Arlauskas, T. Kreouzis, D.D.C. Bradley, and H. Stubb, Initial transport of photogenerated charge carriers in $\pi$-conjugated polymers, Phys. Rev. B 67, 08120 (2003), http://dx.doi.org/10.1103/PhysRevB.67.081201

[20] A. Pivrikas, G. Juška, A.J. Mozer, M. Scharber, K. Arlauskas, N.S. Sariciftci, H. Stubb, and R. Osterbacka, Bimolecular recombination coefficient as a sensitive testing parameter for low-mobility solar-cell materials, Phys. Rev. Lett. 94, 176806 (2005), http:// dx.doi.org/10.1103/PhysRevLett.94.176806

[21] G. Juška, K. Arlauskas, G. Sliaužys, A. Pivrikas, A.J. Mozer, N.S. Sariciftci, M. Scharber, and R. Os- terbacka, Double injection as a technique to study charge carrier transport and recombination in bulk-heterojunction solar cells, Appl. Phys. Lett. 87, 222110 (2005), http://dx.doi. org/10.1063/1.2137454

[22] G. Juška, K. Genevičius, G. Sliaužys, A. Pivrikas, M. Scharber, and R. Osterbacka, Double-injection current transients as a way of measuring transport in insulating organic films, J. Appl. Phys. 101, 114505 (2007), http://dx.doi.org/10.1063/1.2736791

[23] G. Juška, K. Genevičius, N. Nekrašas, and G. Sliaužys, Charge carriers transport, recombination and trapping in organic solar cells studied by double injection technique, IEEE J. Sel. Top. Quantum Electron. 16(6), 1764-1769 (2010), http://dx.doi. org/10.1109/JSTQE.2010.2041752

[24] G. Juška, K. Genevičius, N. Nekrašas, G. Sliaužys, and R. Österbacka, Two dimensional Langevin recombination in regioregular poly(3-hexylthiophene), Appl. Phys. Lett. 95, 013303 (2009), http:// dx.doi.org/10.1063/1.3141513

[25] G. Juška, K. Genevičius, G. Sliaužys, and N. Nekrašas, Two-dimensional Langevin recombination, Phys. Status Solidi C 7, 980-983 (2010), http://dx.doi.org/10.1002/pssc.200982660

[26] A. Reznik, S.D. Baranovskii, O. Rubel, G. Juska, S.O. Kasap, Y. Ohkawa, K. Tanioka, and J.A. Rowlands, Avalanche multiplication phenomenon in amorphous semiconductors: amorphous selenium versus hydrogenated amorphous silicon, J. Appl. Phys. 102, 053711 (2007), http://dx.doi. org/10.1063/1.2776223 


\title{
KRŪVININKỤ PERNAŠA IR REKOMBINACIJA NETVARKIOSIOSE MEDŽIAGOSE
}

\author{
G. Juška, K. Arlauskas, K. Genevičius
}

Vilniaus universiteto Kietojo kūno elektronikos katedra, Vilnius, Lietuva

\section{Santrauka}

Šioje apžvalgoje pateikti krūvininkų pernašos ir rekombinacijos netvarkiosiose medžiagose tyrimo metodai ir gauti rezultatai. Pusiausvyrinių krūvininkų ekstrakcijos tiesiškai didejjančia ịtampa metodas (CELIV) patogus matuojant krūvininkų judrị, tankị ir tūrinị laidumą. Fotogeneruotų krūvininkų ekstrakcijos metodas (photo-CELIV) igalina atskirai matuoti krūvininkų judrio ir tankio relaksaciją po fotosužadinimo. Injektuo- tụ krūvininkų ekstrakcijos metodas (i-CELIV) patogus nustatant elektronų ir skylių judrius tūrinèse heterosandūrose atskirai. Krūvininkų rekombinacijai tirti taip pat pasiūlyti integrinis lèkio trukmès ir dvigubos injekcijos srovès kinetikos metodai. Tiriant amorfinio ir mikrokristalinio silicio, švino oksido ir $\pi$-konjuguotų polimerų bei jų tūrinių heterosandūrų elektrines savybes šiais metodais, gauti svarbūs rezultatai. 